Please cite as:

Hirt, S. 2015. Planning during Post-socialism. International Encyclopedia of Social and Behavioral Sciences (2nd Edition), Vol. 18, pp. 187-192. London: Elsevier.

\title{
Planning during Post-socialism
}

\author{
Sonia A. Hirt \\ Professor and Associate Dean of Academic Affairs \\ College of Architecture and Urban Studies, Virginia Tech \\ Blacksburg, Virginia, USA \\ 540-231-0795; shirt@vt.edu \\ http://profiles.spia.vt.edu/shirt/
}

$\underline{\text { Keywords }}$

Communism, socialism, state socialism, post-communism, post-socialism, transitional countries, Eastern Bloc, Eastern Europe, Soviet Union, urban planning, spatial planning, central planning

\begin{abstract}
$\underline{\text { Abstract }}$
This article analyzes the state of public-sector planning in countries that subscribed to a Marxist, state-socialist ideology during some part of the twentieth century, and especially those countries that comprise the former Eastern Bloc (today often referred to as the "transitional countries"). Central economic planning was a defining feature of state socialism. With its collapse, this type of planning was abandoned. During the early years of post-socialism, all types of public-sector planning, including urban spatial planning, were severely weakened as well. A tentative revival of urban planning can be only recently observed.
\end{abstract}


Thirty years ago, in 1985, nearly half the world was comprised of countries that regarded themselves, and were regarded by others, as socialist. In these countries, located on five continents (predominately Europe, Asia and Africa), a single-party-dominated political apparatus subscribed to a Marxist-Leninist philosophy. Most urban land, large real estate and means of production belonged to the state and its subsidiaries in the form of various public agencies, from municipalities to workers' collectives. The stated goal of socialist regimes was to build a prosperous, egalitarian and classless society. A planned expansion of the economy and a planned distribution of resources among the population were the major means through which this goal was to be achieved.

Yet, today, just a handful of countries carry on the socialist banner. In itself, this fact should amply illustrate that socialism's ostensibly noble goals fell short of realization. Even among those few countries where socialism remains the formal doctrine (e.g., China), capitalist elements of market-led production and resource distribution are now embedded into the socialist system.

This essay analyzes the evolution of public-sector planning (from now on, "planning" for short) in formerly socialist countries over the last quarter of a century: from the time when the "velvet revolutions" spread down throughout Eastern Europe until today (i.e., 1989-2014). The discussion is based primarily on the experiences of the former Eastern Bloc, which comprised the Soviet Union and its East European satellites. Today, after the break-up of the Soviet Union and the two other Eastern-Bloc federations, Czechoslovakia and Yugoslavia, the region includes twenty-eight nations situated over a sixth of the world's land mass, with a total population of about 400 million people. These nations are often referred to as "transitional" (Hirt and Stanilov 2009).

\section{Planning during Socialism}

Marxist-Leninists regarded capitalism as inefficient and exploitative and, therefore, fundamentally flawed socio-economic order that contained the seeds of its self-destruction. Capitalism's alternative, state socialism (in theory, later to be followed by communism) was to ultimately triumph in the world for a number of reasons. One of them was the introduction of systematic state planning of the national economy which would efficiently and justly guide both the production and distribution of resources, thus ostensibly avoiding capitalist-style inequality and periodic economic crises. Prior to the advent of socialism, none of the countries in the region had a record of such planning. In the Soviet Union, the first Five-Year Plan covered the years from 1928 to 1933. Similar plans were adopted in the East European countries, once these countries converted to state socialism after World War II.

The nationwide plans were the poster child of Soviet-style governance. They were prepared by armies of technocrats and stamped by the states' top legislative bodies. They comprised the tip of a strictly hierarchical system of hundreds of lower-level economic plans, which translated the national goals into priorities and strategies for all other administrative divisions (e.g., republics, provinces, cities, towns) and all economic units (e.g., factories, agricultural collectives). This extraordinary scope of the planning activities was only possible because the governing communist parties had nearly full political control over their populations, and because most 
urban land, large real estate and means of production were in state ownership. The planning system was heavily centralized and highly bureaucratic. Local, municipal planning was subordinate to national economic planning. The main function of local planners was to act as technical translators of the higher-level economic goals into the physical layout of cities. For example, if state economic goals were to increase a certain type of industrial production, these goals would have typically been translated into specific mandates for the building of new factories in various cities and regions, which would in turn require that new workers be brought from the countryside. Local planners would receive instructions on expected industrial and population growth. Their job would be to plan and design the new factories, infrastructure, housing and services. Economic and physical planning were not fully integrated in the sense that there was little negotiation between the economic planners (who operated at the national or republican level) and the physical planners (who operated at the local or municipal level). The ones in the former group held much greater powers, although they too were subordinate to the political apparatchiks. Land-use projections were typically conducted at the local level for larger cities and at the republican level for small towns. Local forecasts had to comply with the economic objectives and projections and the spatial standards adopted at the state level; e.g., standards for green space and dwelling space per person (on how the Soviet-era planning model worked, see for example Andrusz 1984).

\section{The Transition Period}

The communist regimes collapsed in a domino-wave fashion throughout the region between 1989 and 1992. The immediate effect was a major political and economic crisis and, in some countries, bloody ethnic wars and national breakdown. From 1989 to 1993, the East European countries lost about a quarter of their aggregate GDP; in the Soviet successor states, aggregated GDP contracted by nearly half. Most countries of the region saw a rise in unemployment rates exceeding a quarter of the population, an explosion of inflation rates into the double and triple digits, a collapse of government-provided safety nets, and a precipitous decline of living standards for the majority of the populations. Social stratification increased sharply as measured by the increases in the Gini coefficients of income distribution throughout the region. On several accounts, the Eastern-bloc meltdown was the deepest and widest economic crisis to occur in peaceful times in modern history. Its causes are well-documented and include the institutional vacuum left over after the collapse of the one-party regimes, the obsolete state of the socialist-era industries, and the erosion of human capital (Dobrinsky et al. 2006). Political reforms and economic recovery followed at varying speeds, with some countries, especially in Central Europe and the Baltic region, leading the pack and eventually joining the European Union, ${ }^{\mathrm{ii}}$ and others still mired in poverty and unrest (Havrylyshyn 2007). In most countries, there was a general consensus that the end of state socialism meant the beginning of reforms leading to market economies and democratic governance; hence, the term "transition" - that is, a pathway from socialism to capitalism-which is commonly applied to the post-socialist period. But interpreting what market economy or what democracy mean - and how to implement them - has varied significantly from country to country. In each, it has been shaped by history and traditions (e.g., see Stark 1992 on "path dependence"). Since strategies and end results have been so different, with some countries embracing a neoliberal version of capitalism (e.g., those in the Baltic region), others retaining elements of social-democratic welfare states (e.g., Slovenia) and third continuously exercising strong state control over resources (e.g., Russia, Kazakhstan), some 
authors have problematized whether the term "transition" is accurate or applicable to all states region-wide (on "theorizing transition," see Pickels and Smith 1998). Perhaps not all countries can be described as "transitioning" toward capitalism; perhaps at least for some "transformation" is a better term (on the diversity of post-socialisms, see for example Bohle and Greskovits 2012).

\section{Privatization and Institutional Transformations}

Regardless of the multiplicity and varying speeds of the post-socialist projects, some level of privatization of public resources was the transformative process common to all countries in the region. Privatization - the transfer of assets and functions from the public to the private sectorcould well be described as the "leitmotif" of the transition (Bodnar 2001, Hirt 2012). In the immediate aftermath of socialism, new constitutions guaranteed the sanctity of private property and mandated the privatization of most urban land, real estate (including almost all dwellings) and means of production, as well as many social services. Some assets were sold; others restituted to those private parties and their successors who could prove ownership predating socialist-era nationalization. In most countries, privatization and restitution were carried out during the early and mid-1990s. However, the process of restituting urban land was highly problematic. This is because often multiple private parties submitted claims to ownership and because much of the urban land was built upon during the years of socialism and thus could not be restituted back to its earlier owners without first demolishing the buildings located on it (which of course was impossible). In addition, the restitution of real estate and means of production was often characterized by corrupt dealings (e.g., large industrial enterprises were sold for pennies to former party aparatchiks). This process greatly contributed to the stratification of post-socialist societies.

Accompanied by the reintroduction of market tenets of production and consumption, privatization and restitution fundamentally transformed economy and society, including the mechanisms of urban development and the planning process. Whereas public authorities had a near monopoly on urban development during the socialist years with the state and its subsidiaries acting as both urban planners and developers, the new paradigm of urban development involved intense competition for land and other resources between plural actors: property owners, private developers, builders, interest groups, political alliances and non-profit organizations, along with governments at all levels and the broader citizenry (e.g., Tsenkova and Nedovic-Budic 2006, Stanilov 2007). A wholly new actor in the development process were the large, multi-national, typically Western (but in some countries also Chinese, Indian, Israeli, Middle Eastern, etc.) firms that entered different countries in the region at different times and in many cases secured preferential treatment from national and municipal governments, ostensibly in the name of faster economic growth. With both private and public resources severely shrinking, especially during the early years of the post-socialist transition, the competition over urban land and resources was particularly ruthless. The weakened and often passive public sector and the newly impoverished masses usually ended up on the losing side.

Another important factor transforming the urban planning and development process was institutional decentralization. National-government involvement in planning matters was sharply 
reduced. The practice of central economic planning was eliminated. Virtually all spatial planning powers were transferred to local, municipal institutions, whose sheer number in most countries increased dramatically. For example, in Hungary, the number of political governments doubled during the 1990s; in Bulgaria and Slovenia it nearly tripled (Tosics 2005). This institutional decentralization was carried out under new laws for municipal self-governance and was seen as an integral part of the overall democratization process. However, as a consequence of the economic downturn, local governments had scarce resources to engage in planning activity. Furthermore, many had no experience with pro-active planning, since during socialism they had only followed national directives. As a result, local governments ended up in the peculiar position of having to plan and implement their plans but with little financial and institutional capacity to do so (Hamilton et al. 2005, Hirt and Stanilov 2009).

\section{Planning's Legitimacy Crisis}

The ideological climate within which planning operates also changed radically throughout the region. In the aftermath of state socialism, most new governments made a sharp turn to the political right. Neo-liberal doctrines espousing the superiority of free-market capitalism put into question the utility of public-sector planning. Many politicians came to view planning as an unwanted vestige of the old socialist system - a phenomenon referred to as a "legitimacy crisis" of planning (Nedovic-Budic 2001, Hirt 2005). This legitimacy crisis affected not just central economic planning - the type of planning that had malfunctioned during socialism and the first to be let go after its collapse. Moral devaluation affected all sorts of government policy, planning and regulation activity. Spatial and housing policies - a traditional public-policy area in most capitalist democracies - were no longer considered an appropriate activity of higher-tier levels of government. The assumption was that the market will guide the production and distribution of resources in more efficient ways that government planners ever could. If government intervention in urban development were needed, it should be conducted by municipal governments, which are much closer to the real-life issues in their communities: hence, the transfer of planning activities to the local level, noted in the previous section. Whereas there were valid reasons to assume that local governments would be closer to the problems "on the ground," in practice they lacked both financial and institutional resources to deal with the serious urban problems leftover from the socialist period: idle industry, decaying housing and infrastructure, environmental degradation, etc. New problems, such as growing poverty and unemployment that were induced by geo-political and national-level events, were ever further beyond what municipal governments could plan for or resolve.

Planning was seen as an outdated activity not just by politicians but by the broader citizenry as well. To a great extent, the problem arose from the legacy of the past. During the socialist period, planners were trained in the technocratic professions (architecture, civil engineering, economics, etc.). They applied their specialized knowledge to implement political priorities set by the communist leadership in the five-year national economic plans. The highly centralized and bureaucratic system left no room for citizen participation in planning, as in other types of government decision-making. Thus, most citizens perceived planning as a faraway activity in 
which they had no input - a perception that greatly contributed to the profession's legitimacy crisis in the 1990s (Hirt 2005). One of the immediate results of this crisis was that, in many towns and cities across the region, people took urban development into their own hands. To begin with, the intensity of building activities, public and private, generally decreased, as it does during any economic meltdown; new housing input dwindled especially dramatically. For example, in the early 1990s, the number of new dwelling units per year in in Czechoslovakia dropped to a fifth of what it had been during the 1980s; in Bulgaria, it went down to a tenth (Stanilov 2007: 173). But where housing and other construction did occur, an unusually high percentage of it was produced not just without long-term planning vision behind it but without government involvement of any sort, even without a building permit. Especially in the nations where ethnic conflict raged on for years, such as the former Yugoslavia and some of the postSoviet republics, urban informality became the new norm (Tsenkova 2012). The problem was aggravated by the fact that updated urban planning laws and regulations did not even exist. Through the 1990s, the last legally valid master plans of many cities dated back to the socialist 1960s and 70s. They were irrelevant and thus largely ignored. Urban development occurred on a piecemeal basis, with private parties often building whatever they wish where they wish-a process sometimes dubbed as "investor urbanism" or even "anarchitecture" (Hirt 2012).

Whereas public-sector withdrawal from urban involvement and ad-hoc development became widespread, there are exceptions. In the capital cities of newly independent countries such as those in the Baltic region and the former Yugoslavia, significant public-sponsored building activities were initiated with the goal of changing the architectural heritage to reflect new national identities (Czaplicka et al. 2009). Similar outcomes can be seen in some of large and economically powerful Soviet successor states, where national governments have invested enormous resources in endowing their capitals with a "global-city" look (e.g., Astana, Kazakhstan) or where powerful city administrations have partnered with large private development corporations to the same end (e.g., Moscow and Saint Petersburg, Russia).

\section{Pressing Challenges and New Planning Instruments}

Many of the severe new challenges of the transition period, such as declining living standards and sharp social stratification, were a result of the broad economic decline and institutional instability of the transition period. However, other challenges arose specifically from the weakened status of planning. Perhaps ironically, during the years of sharp economic decline (the 1990s), the negative consequences of weak planning in many countries were partially offset by the fact that there was limited new building activity, as mentioned above. Thus, while the existing urban housing and infrastructure deteriorated, the sparse private resources invested in new construction guarded against the spread of poorly planned new building forms. This all changed about the year 2000, however, when economic growth picked up, leading to intense new construction in cities, which did not always benefit the broader citizenry.

One obvious example of harmful new development is the loss of public green space. Socialistera cities were generally more compact than their capitalist counterparts (Hirt 2012). This is 
because the state controlled the periphery of cities, channeled the majority of the population towards the high-density mass-housing areas, and prevented sprawling suburban developments of the type common in capitalist contexts, especially in the United States. This changed dramatically after the end of socialism and specifically after the economic stabilization of the late 1990s. The outskirts of large cities were increasingly overtaken by upper- and upper-middleclass residential developments alongside big-box commercial establishments (malls, warehouses, business parks, entertainment complexes, etc.). Urban sprawl became one of the paradigmatic features of post-socialist urban development. The European Commission (2006) described cities in many East European countries (e.g., Bulgaria, Croatia, Estonia, Hungary, Latvia, Poland and Slovakia) as sprawling at rates far exceeding those in Western Europe. The Russian capital Moscow, for instance, lost 750 hectares of forests in its once-lush greenbelt in just two years, from 1999 to 2001. During the same short time period, forests in the metropolitan area decreased by $15 \%$ and grass areas declined by $55 \%$, while impervious surface grew by $26 \%$ (Boentje and Blinnikov 2007). The process of suburbanization, which devoured the once-compact edge of cities, was strengthened by the government fragmentation and decentralization that was instituted during the early post-socialist years. Although a welcome step toward a more democratic, "closer-to-the-people" government, the decentralization process created new institutional actors, small suburban-type governments, which in an era of scarcity competed vigorously to attract new taxes and economic development. The mechanisms they used to compete with their neighbors included making virgin land available for development, softening of building and zoning regulations, and adopting various incentives to attract large-scale developers. The outcomes of such policies are shown by Stanilov and Sykora (2012), for instance: the municipal competition contributed directly to the growth of sprawling developments in the vicinity of the Czech capital of Prague.

Loss of green space affected not only urban outskirts but also inner cities. Socialist-era regimes had demonstrated extraordinary generosity when it came to urban parks and neighborhood green spaces. This was because they had nearly full control over urban land, and because large public spaces well expressed the collectivist ideology of the socialist time period. But intense construction during the years of the post-socialist economy recovery devoured much of what may have been the most positive spatial legacy of the socialist years - the large public green spaces. In the Bulgarian capital of Sofia, for example, about $30 \%$ of public green spaces were "lost in transition" and another 30\% are awaiting the resolution of restitution claims (Hirt 2012).

Another problem that may be attributed to weak planning during the post-socialist transition has been the loss of historic heritage. Although socialist-era regimes had maintained the landmark architecture in city centers, they had quietly left many historic neighborhoods to decay. Still, buildings in these neighborhoods were typically kept; i.e., they were not demolished and replaced with modern structures en masse as was the common case in some West European countries during the mid-1900s. Having survived decades of neglect, about the year 2000 historic areas in prime locations in East European cities were subjected to heavy market pressures. Developers were rarely interested in restoring the old structures. And whereas, in some cities and countries, the historic heritage laws were applied relatively stringently and demolitions were prevented, in others, especially those where growth pressures were immense, the laws were 
applied selectively thus allowing the destruction of invaluable historic buildings. Russia's St. Petersburg, which is one of the largest UNESCO Heritage Sites in the world, is a well-known case (Trumbull 2012). According to the local Architecture Preservation Society in the capital Moscow, some 400 buildings that were federally or locally designated as historic landmarks have been demolished since 1989 in order to make room for glitzy new developments (other experts put the number at 700; Hirt and Stanilov 2009). And this count does not include the hundreds of other historic buildings that were not remarkable enough to make it into the official lists.

A fourth problem that planning failed to address is the change in mobility patterns. Socialist-era cities had fairly sophisticated mass-transit systems which served the residents of their compact neighbourhoods well. Following from the sprawl of the post-socialist metropolis and the limited investment in public infrastructure made in most countries, the urban citizenry became increasingly dependent on individual automobiles as the chief means of travel. In most East European countries, car ownership more than doubled during the post-socialist period; it is now rapidly increasing in the Caucasus region and Central Asia. For example, in Latvia, car ownership increased from 83 to 297 cars per 1000 people in about twenty years. Planners in this country's major cities, especially the capital of Riga, regard traffic congestion and air pollution as some of the worst current urban problems, yet little has been done to mitigate them. Autoinduced urban pollution has become an especially acute problem in the poorer countries, where much of the automobile stock comprises old second- and third-hand cars imported from Western Europe which do not meet contemporary emission standards (Hirt and Stanilov 2009).

A fifth planning-related challenge stemmed from the sharpening stratification of post-socialist societies. Surely, urban planners and policy-makers could have done little to prevent the yawning gap that developed between the handful of newly rich and the majority of the national populations during the first years of the post-socialist transition. However, in failing to produce an appropriate combination of policies, regulations and incentives to mitigate some of the negative outcomes of the post-socialist "investor urbanism," planners contributed to converting social stratification into a spatial phenomenon. The socialist state had succeeded, albeit through authoritarian means, to reduce social segregation in cities. The mass-housing estates, specifically, were homes to wide and diverse segments of the population, from the intelligentsia to the working classes, and only the top regime aparatchiks lived in elite enclaves either in the centres of capital cities or in occasional securitized compounds at the urban edge. Assuming we consider spatial integration a positive phenomenon, we could say its benefits were all but lost in post-socialist times. Middle and upper-middle-class residents of post-socialist cities have been increasingly exiting the mass-housing districts to settle either in the gentrifying neighbourhoods of city centres or in the growing leafy suburbs. In some countries, the mass-housing areas are now occupied predominantly by elderly pensioners or ethnic minorities. In addition, in fastgrowing cities, which attract residents from small towns and the countryside in search of jobs and services, the new peripheries very much resemble the type of slum areas found in the outskirts of the large cities of the developing world (e.g., Tsenkova 2012). In the meantime, explicitly privatized urban forms, especially highly securitized gated communities, have gained popularity among new urban elites (e.g., Hirt 2012).

The five planning-related challenges discussed above certainly do not comprise an exhaustive list. Many other serious urban spatial issues remain; for example, the need to adapt the extensive 
brownfields occupied by the derelict socialist-era industries to new use; the need to reconstruct the vast socialist-era housing stock, some of which is in perilously poor shape; and the need to deal with the poor quality of structures constructed during the lawless 1990s. These issues have been successfully addressed only in the most prosperous parts of the former Easter Bloc: in East Germany and, to an extent, in the Central European states. However, there are signs that urban spatial planning is recovering from its crisis region-wide and could, therefore, become more instrumental in solving some of the serious challenges. To begin with, the effects of chaotic urban development (congestion, pollution, etc.) of the 1990s have become so obvious that today there is a much broader political acceptance of planning as a legitimate municipal government function than there was a decade or two ago. Urban planning activities are definitely on the rise across the region. New master plans have by now been adopted for about every large city in the region; in many cases, the new master plans have in fact already undergone multiple revisions and amendments (Hirt and Stanilov 2009). Alongside, the neighborhood-scale regulatory plans have been continuously updated and their implementation mechanisms have been strengthened, all of which sharply reduce the possibility of going back to the 1990s-style "free-for-all" growth.

In addition, other types of planning are taking root as well. One new instrument is strategic spatial planning. Like master plans, strategic plans have a citywide focus. However, they are typically based on a shorter time span. Also, instead of attempting to address the full range of urban problems as master plans do, strategic plans aim to resolve only a specific set of pressing challenges. A "typical" focus includes: improving city competitiveness in the era of globalization, fostering urban economic growth, promoting municipal financial reform, improving quality of life via modernizing housing and infrastructure, and enhancing urban sustainability (including through adopting local versions of Agenda 21). Many major cities in the region have by now passed strategic plans in addition to their traditional master plans (for example, Bratislava, Budapest, Prague, Riga, Sofia, Tallinn, Tirana and Zagreb). Because of their tangible focus, the strategic plans have attracted much wider interest from the citizenry than have traditional master plans. The second new type of planning is regional development planning. Regional plans are prepared by the regional layers of government created in the new member states of the European Union. They are essentially economic development plans, which the European Union requires in order to direct its massive structural funds. These funds aim to reduce regional disparities in income, wealth and opportunities across the European Union and have been employed primarily in the new member states. The regional development plans do not necessarily have a spatial component. Still, in thinking through region-wide economic and other issues comprehensively, they have come to fill the planning vacuum that was created after the collapse of Soviet-style central economic planning. Finally, some planning activities have returned to the national level of government. Specifically, many countries have adopted national environmental strategies as well as action plans focused on specific environmental issues (e.g., air quality, water quality, biodiversity, waste disposal). This is especially true for the new European Union member states, which have been required to harmonize their national environmental legislation with European Union standards. Overall, whereas the era of virtually no planning in the transitional countries may be over, only time will tell whether the new planning activities will succeed in substantially improving the quality of life of the 400 million people who live in this part of the world. 


\section{References}

Andrusz, G. 1984. Planning and Urban Development in the USSR, State University of New York Press, Albany.

Bodnaŕ, J. 2001. Fin de Millénaire Budapest: Metamorphoses of Urban Life. University of Minnesota Press, Minneapolis.

Boentje, J. and Blinnikov, M. 2007. Post-Soviet forest fragmentation and loss in the Green Belt around Moscow, Russia (1991-2001): A remote sensing perspective. Landscape and Urban Planning, 82(4), 208-221.

Bohle, D. and Greskovits, B. 2012. Capitalist Diversity on Europe's Periphery. Cornell University Press, Ithaca.

Czaplicka, J., Gelazis, N., and Ruble, B. 2009. Cities after the Fall of Communism: Reshaping Cultural Landscapes and European Identity. Johns Hopkins University Press, Baltimore.

Dobrinsky, R., Hesse, D., and Traeger, R. 2006. Understanding the Long-term Growth Performance of the East European and CIS Economies. UNECE (United Nations Economic Commission for Europe), Geneva.

European Commission. 2006. Urban sprawl in Europe: The ignored challenge. Directorate general Joint Research Center, Copenhagen.

Havrylyshyn, O. 2007. Fifteen Years of Transformation in the Post-Communist World. CATO Institute, Washington, DC.

Hamilton , F., Andrews, K. and Pichler-Milanovic, N. 2005 . Transformation of Cities in Central and Eastern Europe: Towards Globalization. United Nations University Press, New York.

Hirt, S. 2005. Planning the post-communist city: Experiences from Sofia. International Planning Studies, 10(3-4), 219-240.

Hirt, S. 2012. Iron Curtains: Gates, Suburbs and Privatization of Space in the Post-socialist City. Wiley-Blackwell, Oxford.

Hirt, S., Stanilov, K., 2009. Twenty Years of Transition: The Evolution of Urban Planning in Eastern Europe and the Former Soviet Union, 1989-2009. United Nations Human Settlements Programme, Nairobi.

Nedović-Budić, Z. 2001. Adjustment of planning practice to the new Eastern and Central European context. Journal of the American Planning Association, 67(1), 38-52. 
Pickles, J. and Smith, A. (Eds.). 1998. Theorizing Transition: The Political Economy of Postcommunist Transformations. Routledge, London.

Stanilov, K. (Ed.). 2007. The Post-socialist City: Urban Form and Space Transformations in Central and Eastern Europe after Socialism. Springer, Dordrecht.

Stanilov, K. and L. Sykora. 2012. Planning, markets, and patterns of residential growth in metropolitan Prague. Journal of Architectural and Planning Research 29(4): 278-291.

Trumbull, N. 2012. Urban pulse - Claiming "The Right to the City": Architectural preservation in St. Petersburg as cultural and political Catalyst. Urban Geography, 33(7), 1000-1007.

Tosics, I. 2005. City development in Central and Eastern Europe since 1990: The impact of internal forces. Transformation of Cities in Central and Eastern Europe: Towards Globalization, 44-78, United Nations University Press, New York.

Tsenkova, S. 2012. Urban planning and informal cities in Southeast Europe. Journal of Architectural and Planning Research, 29(4), 292-305.

Tsenkova, S., and Nedovic-Budic, Z. (Eds.). 2006. The Urban Mosaic of Post-socialist Europe: Space, Institutions and Policy. Springer, Heidelberg.

Stark, D. 1991. Path Dependence and Privatization Strategies in East Central Europe. East European Politics and Societies 6 (December), 17-54.

i

Alternative terms are "state socialist" or "communist." Without delving into the differences between these terms, for simplicity purposes from now on I will use the term "socialist."

ii

The following former Eastern-Bloc countries have joined the European Union: Bulgaria, Croatia, Czech Republic, Estonia, Hungary, Latvia, Lithuania, Poland, Romania, Slovakia and Slovenia. Several others are at various stages of accession and negotiation. 